\begin{tabular}{|c|c|c|}
\hline & NERACA & 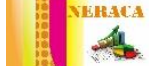 \\
\hline & JURNAL PENDIDIKAN EKONOMI & \\
\hline UMP & $\begin{array}{c}\text { http://journal.umpalangkaraya.ac.id/index.php/neraca } \\
\text { Volume } 6 \text { Nomor 1, November } 2020 \text { (37-43) }\end{array}$ & axis \\
\hline
\end{tabular}

\title{
PENINGKATAN KETERAMPILAN MENULIS ANEKDOT MENGGUNAKAN STRATEGI GENIUS LEARNING UNTUK SISWA KELAS XI IPS 2 SMA NEGERI 1 DUSUN SELATAN TAHUN 2015/2016 \\ Improvement Of Anecdot Writing Skills Using Genius Learning Strategy For \\ Grade XI IPS 2 Students SIMA Negeri 1 Dusun Selatan Academic Year 2015/2016 \\ Nuriati
}

SMA Negeri I Dusun Selatan, Barito Selatan, Kalimantan Tengah, Indonesia

ARTIKEL INFO

Diterima

September 2020

Dipublikasi

November 2020

*e-mail :

rikuatnospd@yahoo.co.id

\section{ABSTRAK}

Subjek penelitian yang dijadikan subjek tindakan adalah 32 siswa kelas XI IPS 2 di SMA Negeri I Dusun Selatan. Model penelitian yang digunakan adalah Penelitian Tindakan Kelas (PTK). Prosedur pelaksanaan tindakan dan pelaksanaan tindakan tersebut dibagi menjadi dua bagian. Setiap siklus dilakukan tiga kali. Penelitian ini difokuskan pada masalah yang berkaitan dengan peningkatan keterampilan menulis total dengan menerapkan strategi pembelajaran genius. Data diperoleh melalui (I) angket, (2) catatan lapangan, dan (3) dokumentasi berupa tugas siswa dan foto kegiatan selama penelitian. Teknik analisis data dilakukan dengan teknik deskripsi kualitatif dan kuantitatif. Kriteria keberhasilan yang dicapai siswa dalam penelitian ini dilihat dari perubahan ke arah yang lebih baik dan peningkatan tindakan dan hasil pembelajaran dalam praktik menulis anekdot. Keberhasilan ini dilihat dari dua kriteria yaitu keberhasilan proses dan produk. Hasilnya menunjukkan sebagai berikut. Pertama, penggunaan strategi pembelajaran genius dapat meningkatkan kualitas proses pembelajaran menulis anekdot. Adanya peningkatan proses pada aspek situasi pembelajaran, fokus siswa, dan keaktifan membuat perubahan yang positif sehingga pembelajaran menulis anekdot menjadi lebih menarik dan menyenangkan. Kedua, pembelajaran dengan menggunakan strategi pembelajaran genius dapat meningkatkan kemampuan menulis anekdot siswa. Hal ini terlihat dari skor rata-rata keterampilan menulis anekdot sebelumnya adalah 64,53 , sedangkan setelah melalui siklus II skor rata-rata menjadi 85,00 . Hal ini menunjukkan adanya peningkatan sebesar 20,47.

Kata kunci: Menulis, Genius Learning.

\section{ABSTRACT}

The research subjects who were subjected to action were 32 students of class XI IPS 2 at SMA Negeri I Dusun Selatan. The research model used is Penelitian Tindakan Kelas (PTK). The procedure for implementing the action and implementing the action is divided into two parts. Each cycle was conducted three times. This study is focused on problems related to improving anecdotal writing skills by implementing genius learning strategies. The data were obtained through (I) questionnaires, (2) field notes, and (3) documentation in the form of student assignments and photos of activities during the research. The data analysis technique was carried out by qualitative and quantitative description techniques. The success criteria achieved by students in this study were seen from a change for the better and an increase learning actions and results in the practice of writing anecdotes. This success is seen from two criteria, that are process and product success. The results showed the following. First, the use of genius learning strategies can improve the quality of the learning process to write anecdotes. There is an increase in the process in the aspects of learning situations, student focus, and activeness, making positive changes so that learning to write anecdotes is more interesting and enjoyable. Second, learning using genius learning strategies can improve students' ability to write anecdotes. This can be seen from the previous average score of anecdotal writing skills was 64.53 , while after going through cycle II the average score became 85.00 . This shows that there is an increase of 20.47 .

Keywords: Writing, Genius Learning. 


\section{PENDAHULUAN}

Peningkatan kualitas pembelajaran merupakan salah satu peningkatan mutu pendidikan secara keseluruhan. Marsigit (Sutama, 2000) menyatakan bahwa ahli-ahli kependidikan telah menyadari mutu pendidikan sangat tergantung pada kualitas guru dan kualitas pembelajarannya, sehingga peningkatan kualitas pembelajaran merupakan isi dasar bagi peningkatan mutu pendidikan secara nasional.

Keterampilan menulis merupakan keterampilan yang bersifat mekanistis. Keterampilan menulis tidak mungkin dikuasai hanya melalui teori, tetapi dilaksanakan melalui latihan dan praktik yang teratur sehingga menghasilkan tulisan yang tersusun baik. Keterampilan menulis menghendaki penguasaan berbagai unsur kebahasaan dan unsur di luar bahasa itu sendiri yang akan menjadi isi karangan. Bagi kebanyakan orang, menulis merupakan kegiatan yang menyenangkan. Bahkan bagi sebagian orang, menulis adalah sebuah keharusan.

Misalnya, para wartawan media cetak atau elektronik yang bertugas melaporkan suatu peristiwa dengan rangkaian kata-katanya. Hal serupa ditegaskan (Tarigan, 2008:23) bahwa tulisan dapat membantu kita menjelaskan pikiran-pikiran kita.Permasalahan tersebut harus diperhatikan arena kemampuan menulis anekdot sangat berperan dalam pembelajaran Bahasa dan Sastra Indonesia. eksanekdot mempunyai kontribusi yang besar pada pembelajaran keterampilan menulis bentuk-bentuk lainnya. Oleh karena itu, guru sebagai salah satu komponen sentral dalam proses pembelajaran agar proses belajar mengajar dapat berhasil dengan baik dan terlaksana secara optimal. Upaya untuk membantu siswa mengatasi rendahnya keterampilan menulis anekdot, salah satunya dapat ditempuh dengan cara meningkatkan penggunaan strategi dalam proses pembelajaran. Praktik menulis anekdot akan dilakukan dengan baik jika ada perasaan senang atau tertarik dari siswa terhadap kegiatan menulis tersebut. Berdasarkan latar belakang masalah di atas, melalui penelitian ini akanditerapkan strategi genius learning untuk meningkatkan kemampuan menulis anekdot siswa kelas Kelas XI IPS 2 SMA Negeri I Dusun Selatan. Melalui strategi genius learning ini diharapkan dapat meningkatkan kemampuan menulis anekdot siswa.

Menulis merupakan kegiatan seseorang untuk menggambarkan suatu bahasa agar mudah dipahami oleh orang lain. Bagi sebagian besar orang, menulis adalah aktifitas yang membosankan. Namun, pada hakikatnya menulis adalah aktifitas yang sangat menyenangkan. Hal tersebut dikarenakan, menulis mampu menciptakan gagasan dan kreativitas yang baik.Selain itu, menulis dapat memberikan manfaat ganda yang menggairahkan, seseorang dapat menularkan ide yang bermanfaat kepada khalayak luas.Tabroni (2007: 5I) mengungkapkan bahwa tulisan dapat dijadikan sebagai sarana untuk menyalurkan aspirasi dan uneg-uneg kepada pemerintah atau siapa saja yang dapat membahayakan dan merugikan orang banyak.

Genius learning merupakan strategi belajar untuk membangun lingkungan pembelajaran yang kondusif.Kondisi kondusif ini merupakan syarat mutlak demi tercapainya hasil belajar yang maksimal.

Strategi genius learning disusun berdasarkan hasil riset mutakhir mengenai berbagai disiplin ilmu, terutama cara kerja otak dan memori (Gunawan, 2012: 8). Genius learning mengakomodasikan gaya belajar dan mengembangkan kecerdasan siswa dengan pendekatan preferensi sensori berdasarkan visual, auditori, dan kinestetik. 


\section{METODE PENELITIAN}

Penelitian ini menggunakan penelitian tindakan kelas (PTK). Penelitian melibatkan peneliti yang berkolaborasi dengan guru sejawat Bahasa Indonesia SMA Negeri I Dusun Selatan.

Tempat penelitian dilaksanakan di SMANegeri I Dusun Selatan yang berlokasi di Jalan Ki Hajar Dewantara Buntok. Subjek yang menerima tindakan adalah siswa kelas $\mathrm{XI}$ Jurusan IPS 2 yang berjumlah 32 siswa. Kelas ini dipilih dengan beberapa pertimbangan, antara lain dalam keterampilan menulis siswanya masih tergolong rendah.

Penelitian ini dilaksanakan oleh peneliti sebagai subjek yang melaksanakan tindakan pembelajaran, sedangkan yang melakukan pengamatan adalah guru teman sejawat. Penelitian tindakan kelas ini dilaksanakan pada 27 Januari 2016 sampai 3 Maret 2016. Khusus di kelas XI IPS 2pembelajaran Bahasa Indonesia berlangsung setiap Senin dan Rabu. Senin jam ke-I dan ke2 yaitu pukul 07.00 WIB sampai 08.30.

Prosedur penelitian menggunakan siklus melalui empat langkah yaitu perencanaan, tindakan, observasi dan refleksi. Teknik pengumpulan data pada penelitan ini menggunakan strategi genius learning.

Instrumen ini berupa pertanyaan yang memerlukan jawaban tertulis. Angket meliputi angket pratindakan dan angket pasca tindakan. Angket pratindakan yang diberikan sebelum tindakan dilakukan untuk mengetahui keterampilan menulis anekdot siswa sebelum diberi tindakan.Angket pascatindakan digunakan untuk mengetahui bagaimana penerapan strategi genius learning dalam pembelajaran menulis anekdot dan mengetahui tingkat pemahaman siswa setelah menerapkan strategi genius learning.

Pengujian keabsahan data digunakan teknik triangulasi dengan cara memanfaatkan sumber. Triangulasi dilakukan dengan sumber membandingkan dan mengecek balik derajat kepercayaan suatu informasi yang diperoleh melalui waktu dan alat yang berbeda dalam penelitian kualitatif.

Dalam analisis data, peneliti membandingkan isi catatan yang dilakukan dengan kolaborator, kemudian data diolah dan disajikan secara deskriptif kuantitatif dan kualitatif.

Sesuai dengan karakteristik penelitian tindakan, keberhasilan penelitian tindakan ini ditandai adanya perubahan ke arah perbaikan, baik terkait dengan suasana belajar dan pembelajaran. Indikator keberhasilan dapat ditentukan berdasarkan proses dan produk. Keberhasilan berdasarkan proses apabila dalam penelitian ini terjadi peningkatan keterampilan dalam menulis anekdot dibandingkan dengan sebelum diadakannya tindakan. Hal ini, dapat dilihat adanya perubahan aktivitas siswa dalam kegiatan pembelajaran menulis anekdot dengan model pembelajaran genius learning, meliputi siswa aktif berpartisipasi dalam proses pembelajaran menulis anekdot. Siswa mampu menulis ide atau gagasan dari hasil pengamatan dengan lingkungan sekitarnya dengan demikian, siswa akan terampil dan kreatif dalam menulis anekdot.

\section{HASIL PENELITIAN DAN PEMBAHASAN}

\section{Pra Siklus}

Sebelum pelaksanaan tindakan dimulai, dilakukan observasi mengenai minat siswa terhadap pembelajaran Bahasa Indonesia khususnya menulis anekdot. Data yang diperoleh melalui angket merupakan informasi awal pengalaman siswa dalam menulis anekdot. Melalui angket informasi awal tabel tersebut diketahui bahwa tingkat minat siswa kelas XI IPS 2 SMANegeri I Dusun Selatan terhadap pembelajaran Bahasa Indonesia khususnya menulis anekdot masih rendah, dibuktikan dengan persentasi sebanyak 53,33\% siswa. $76,67 \%$ siswa masih merasa kesulitan 
menuangkan ide dalam menulis anekdot. $\mathrm{Hal}$ ini dikarenakan siswa jarang berlatih menulis anekdot di rumah maupun di sekolah. Namun demikian, mereka sadar bahwa pembelajaran menulis anekdot memerlukan banyak latihan dan siswa berkeinginan dapat menulis anekdot dengan baik dibuktikan dengan $90 \%$ siswa yang berminat. Pembelajaran yang dilakukan selama ini dirasa belum membuat siswa mahir dalam menulis, khususnya menulis anekdot.

Pelaksanaan penelitian tindakan kelas dalam pembelajaran menulis anekdot dengan strategi genius learning pada siswa kelas XI IPS 2 dilaksanakan dua siklus. Penelitian tindakan ini, peneliti bekerja sama dengan guru bahasa Indonesia, yaitu lbu Erna Nurul Huda, S. Pd. sebagai teman sejawat yang mengajar di kelas lain sekaligus kolaborator. Kegiatan pembelajaran dari pratindakan sampai siklus kedua dilaksanakan oleh peneliti. Sementara guru kolaborator mengamati jalannya pembelajaran berdasarkan kesepakatan dengan guru kolaborator yang disesuaikan dengan jadwal aktif sekolah.

\section{Siklus I}

Perencanaan disusun bertujuan merencanakan pelaksanaan tindakan untuk meningkatkan keterampilanmenulis anekdot siswa. Setelah dilakukan tes awal menulis anekdot diketahui skor rata-rata kemampuan siswa sebesar 64,53. Skor rata-rata tersebut tentu masih di bawah Kriteria Ketuntasan Minimal (KKM) pelajaran bahasa dan sasatra Indonesia, yaitu 75 dan masih di bawah kriteria keberhasilan penelitian, yakni lebih dari atau sama dengan 75. Berdasarkan hasil yang ada, peneliti dan kolaborator memutuskan untuk menggunakan media karton struktur berbantu kata krisis yang sudah ditentukan.

Melalui strategi Genus Learning kesulitan mencari ide dalam menulis anekdot karena siswa dapat mengembangkan ide yang mereka peroleh dengan meningkatnya 3,34 poin dari pratindakan ke siklus I. Sementara itu, pada aspek organisasi, tulisan siswa sudah mencakup dari kelima struktur anekdot, yaitu abstraksi, orientasi, krisis, reaksi, dan koda. Terlihat pada rata-rata skor yang diperoleh saat pratindakan sebesar 13, I5 lalu meningkat 2,54 poin menjadi I5,69 pada siklus I.

Pada penggunaan bahasa yang digunakan siswa, sebagian sudah memperhatikan struktur penulisan kalimat yang minimal sesuai dengan subjek dan predikatnya. Keefektifan kalimat yang digunakan siswa juga lebih tepat dan tidak berbelit-belit. Hal ini seperti tertulis pada tabel, yang mengalami peningkatan sebesar I,75 poin. Saat pratindakan sebesar I2,8I dan kemudian naik menjadi I4,56 pada siklus I.

Aspek selanjutnya adalah kosakata. Pada kosakata hal yang harus diperhatikan adalah penggunaan kata. Penggunaan kata kaitannya dengan pemilihan kata yang tepat dan sesuai dengan apa yang diceritakan dalam teks anekdot. Pada aspek ini sebelum diberi tindakan diperoleh skor rata-rata 15,48 dan setelah diberi tindakan pada siklus I diperoleh skor rata-rata 18. $\mathrm{Hal}$ ini menunjukkan bahwa telah terjadi peningkatan 2,52 poin pada siklus I. Meningkatnya skor rata-rata tersebut, menunjukkan bahwa pada siklus I aspek kosakata telah mengalami peningkatan.

\section{Siklus II}

Pada siklus II, tindakan yang diberikan hampir sama dengan tindakan pada siklus I. Dalam siklus II ada beberapa penambahan tindakan sebagai perbaikan tindakan siklus I. $\mathrm{Hal}$ tersebut bertujuan agar pembelajaran menulis teks anekdot lebih optimal, baik dilihat dari proses maupun hasilnya. Pembelajaran menulis anekdot dengan strategi genius learning dapat mendorong siswa untuk mempelajari lebih dalam tentang menulis anekdot. Hal itu diketahui dari 21,87\% siswa atau 7 siswa yang menyatakan sangat 
setuju dan 19 siswa atau 59,37\% menyatakan setuju. Hanya $18,76 \%$ atau 6 siswa yang menyatakan kurang setuju bahwa pembelajaran menulis anekdot dengan strategi genius learning dapat menarik minat siswa untuk mempelajari lebih dalam tentang menulis anekdot.

Sebanyak 10 atau $31,25 \%$ siswa sangat setuju dan 15 atau $46,88 \%$ siswa menyatakan setuju jika pembelajaran menulis anekdot dengan strategi genius learning dilakukan terus menerus, agar siswa lebih paham dan terampil dalam menulis anekdot. Hanya sebanyak 7 siswa atau $21,87 \%$ siswa dalam kelas XI IPS 2 yang menyatakan kurang setuju dengan pernyataan tersebut. Hal itu menunjukkan bahwa siswa merasa pembelajaran menulis anekdot akan lebih optimal jika dilakukan dengan strategi genius learning.

Pernyataan siswa agar pembelajaran menulis anekdot dengan strategi genius learning itu terus dilakukan dikarenakan siswa merasa strategi genius learning yang diterapkan sangat menarik serta membantu sekali dalam praktik menulis anekdot, karena strategi tersebut mengombinasikan teknikteknik pembelajaran yang menyenangkan dan sesuai dengan kondisi siswa, sehingga keterampilan menulis anekdot siswa pun meningkat. Hal itu dapat diketahui dari pernyataan 9 atau $21,12 \%$ siswa menyatakan sangat setuju dan 23 atau $71,88 \%$ setuju bahwa strategi genius learning yang diterapkan membantu sekali dalam praktik menulis anekdot. Selain itu, sebanyak 20 atau $62,50 \%$ siswa menyatakan sangat setuju dan $34,37 \%$ atau II siswa lainnya menyatakan setuju bahwa menggunakan strategi genius learning membantu sekali dalam keterampilan menulis anekdot.

Pembahasan hasil penelitian ini meliputi (I) informasi awal danpengalaman siswa dalam menulis anekdot serta tes awal menulis anekdot (pratindakan), pelaksanaan tindakan kelas menulis anekdot dengan strategi genius learning, dan (3) peningkatan keterampilan menulis anekdot dengan strategi genius learning.

Peningkatan yang dicapai pada aspek kosakata ini cukup signifikan. Terlihat pada diagram di atas. Pada rata-rata kemampuan kosakata awal siswa hanya sebesar 15,48. Kemudian dilakukan tindakan pada siklus I, mengalami peningkatan sebesar 2,52 poin menjadi 18. ada siklus II skor rata-rata yang diperoleh menjadi 20,84 , meningkat 2,84 poin. Sesuai dengan peningkatan tersebut maka dapat disimpulkan bahwa penggunaan strategi genius learning dalam pembelajaran menulis anekdot berhasil meningkatkan aspek kosakata tulisan anekdot.

Dari diagram di atas, dapat diketahui adanya peningkatan pada aspek mekanik dari tes pratindakan, siklus I, dan siklus II. Skor rata-rata aspek mekanik pada tes pratindakan sebesar 2,97. Setelah dikenai tindakan pada siklus I, skor rata-rata meningkat sebesar 0,8 poin menjadi 3,77. Pada siklus II, skor ratarata aspek mekanik meningkat 0,23 menjadi 4 . Peningkatan yang dicapai pada aspek mekanik dalam tulisan anekdot siswa secara keseluruhan mengalami peningkatan.Jadi, dapat disimpulkan bahwa strategi genius learning dapat meningkatkan skor rata-rata aspek mekanik dalam menulis anekdot.

\section{KESIMPULAN}

Berdasarkan rumusan masalah dan hasil penelitian serta pembahasan dalam penelitian tindakan kelas dapat disimpulkan bahwa sebelum dilakukan tindakan, pengetahuan, dan kemampuan menulis anekdot masih rendah. Kegiatan praktik menulis anekdot belum pernah dilaksanakan karena kurikulum sebelumnya tidak ada materi mengenai anekdot. Kualitas pembelajaran menulis anekdot meningkat dengan menggunakan strategi genius learning. Adanya peningkatan dan perubahan positif 
Jurnal Pendidikan Ekonomi

pada aspek situasi belajar, perhatian, keaktifan, serta proses belajar mengajar menjadikan pembelajaran menulis anekdot lebih menarik, menyenangkan, dan tidak membosankan.

Pembelajaran dengan strategi genius learning dapat meningkatkan hasil kemampuan menulis anekdot. Hal ini terlihat dari skor rata-rata menulis anekdot sebelum diberi tindakan adalah 64,53 , setelah diberi tindakan pada akhir siklus I skor rata-rata menjadi 75,58. Skor rata-rata menulis anekdot pada akhir siklus II yaitu 85,00 . Hal tersebut menunjukkan adanya peningkatan sebesar 20,47 poin. Secara keseluruhan pada akhir siklus II ini semua aspek dan kriteria menulis anekdot mengalami peningkatan yang cukup signifikan.Dari hasil penelitian di atas terbukti bahwa penggunaan strategi genius learning dinilai berhasil dan dapat meningkatkan kemampuan menulis anekdot siswa kelas XI IPS 2 SMA Negeri I Dusun Selatan.

Berdasarkan kesimpulan dan hasil penelitian di atas, saran yang dapat dikemukakan bagi siswa, hendaknya selalu memperhatikan apa yang disampaikan oleh guru. Siswa yang sudah mendapatkan hasil baik harus dipertahankan bahkan harus ditingkatkan. Bagi siswa yang belum memperoleh hasil baik, jangan pernah patah semangat, terus berlatih agar dapat meningkat. Bagi guru bahasa Indonesia, disarankan untuk menggunakan strategi genius learning alam pembelajaran menulis anekdot agar pembelajaran lebih menarik, inovatif, menyenangkan, dan tidak membosankan. Berusaha memperhatikan dan memahami setiap kesulitan belajar siswa kemudian dicari solusi dan pemecahannya. Guru hendaknya selalu kreatif dan inovatif dalam pelaksanaan proses pembelajaran khususnya pembelajaran menulis anekdot.

\section{DAFTAR PUSTAKA}

Chaedar dan Senny Suzanna Alwasilah. 2008. Pokoknya Menulis. Bandung:Kiblat

Arikunto, Suharsimi. 2009. Penelitian Tindakan Kelas. Jakarta : PT Bumi Aksara.

Asmani, Jamal Ma'mur. 20II. Buku Panduan Internalisasi Pendidikan Karakter di Sekolah. DIVA Press: Yogyakarta

Dananjaya, Utomo, 2012. Media Pembelajaran Aktif. Bandung: Nuansa

Gunawan, Adi.W. 2013. Genius Learning Strategy. Jakarta : PT Gramedia.

Kompetensi Bahasa dan Karakter Siswa. Pendidikan Bahasa, Sastra Indonesia, dan Daerah FKIP Universitas Muhammadiyah Surakarta.

Madya, Suwarsih. 2006 . Panduan Penelitian

Tindakan. Yogyakarta: Lembaga

Penelitian IKIP Yogyakarta.

Moleong, Lexy J. 2006. Metodologi Penelitian Kulitatif. Bandung: PT Remaj Rosdakarya Nuraini, Fatimah. 2013. Teks Anekdot Sebagai Sarana Pengembangan

Nurgiyantoro, Burhan. 2010. Penilaian dalam

Pengajaran Bahasa dan Sastra.

Yogyakarta: BPFE.

Pardjono dkk. 2007. Panduan Penelitian

Tindakan Kelas. Yogyakarta: Lembaga Penelitian Universitas Negeri Yogyakarta.

Pendidikan Nasional Direktorat Jenderal Pendidikan Dasar dan Menengah Direktorat Pendidikan Lanjut Pertama.

Putra, Chandra A, dkk. 2019. Upaya Meningkatkan Keterampilan Menulis Karangan Deskripsi Menggunakan Model Explicit Instruction Berbasis Teknologi Multimedia. Seminar Internasional Riksa Bahasa.

Rose dan Nicholl. 2012. Accelerated Learning for The Century 2/th Century cara Belajar Cepat Abad XXI. Bandung : Nuansa.

Septiana, Yulisa dan Muhammad Jailani. 2019. Upaya Meningkatkan Motivasi Belajar dan Hasil Belajar Ekonomi dengan 
Jurnal Pendidikan Ekonomi

Menggunakan Model Student Team

Achievement Division (STAD) pada

Kelas $X$ di SMA Negeri I Katingan

Hilir. Neraca: Jurnal Pendidikan Ekonomi 4(2):33-40.

Siswanti, Reni. 201I. —Peningkatan Keterampilan Menulis Narasi dengan Media Kartun Benny \& Mice pada Siswa Kelas XB SMAN I Piyungan Bantulll. Skripsi SI. Yogyakarta: Jurusan Pendidikan Bahasa dan Sastra Indonesia FBS UNY.

Sudjana, Nana. 2000. Cara Belajar Siswa Aktif dalam Proses Belajar Mengajar. Bandung: Sinar Baru Algesindo..

Sutama. 2000. Metode Penelitian Pendidikan. Surakarta: Penerbit Setiaji

Tabroni, Roni. 2007. Melejit Potensi Mengasah Kreativitas Menulis Artikel. Bandung: Nuansa

Tarigan, H.G. 2008. Menulis Sebagai Suatu Keterampilan Berbahasa. Bandung: Angkasa.

Wachidah, Siti. 2004. Pembelajaran Teks Anekdot. Jakarta: Departemen

Wibowo, Basuki, Dr. 2003. Penelitian Tindakan Kelas. Jakarta: Departement Pendidikan Nasional.

Wijana, I Dewa Putu. 1995. Pemanfaatan Teks Humor dalam Pegajaran Aspek-Aspek Kebahasaan. II/I995. Halaman 23-30.

Yunita, Erna. 2013. -Pengaruh Genius Learning dengan Media Flash Card terhadap Hasil Belajar IPA Siswa SMP Negeri 12 Semarang Tahun Ajaran 2013/20I4ll. Skripsi SI. Semarang: IKIP PGRI Semarang 